\section{Western European Specialists Section}

Program: Monday, June 29, 9:30 a.m.-12:30 p.m.

Executive: Sunday, June 28, 8:00-9:00 a.m.; Tuesday, June $30,4: 30-5: 30$ p.m.

Classical, Medieval, Renaissance Discussion Group: Sunday, June 28, 2:00-4:00 p.m.

Conference Program Planning-New Orleans, 1988: Monday, June 29, 8:00-9:00 a.m.

European Conference: Sunday, June 28, 9:30-11:00 a.m.; Monday, June 29, 2:00-4:00 p.m.

Membership/General Discussion Group: Satur- day, June 27, 2:00-4:00 p.m.

Newsletter: Saturday, June 27, 4:30-5:30 p.m.

Publications: Sunday, June 28, 2:00-4:00 p.m.

Research and Planning: Tuesday, June 30, 9:30-11:00 a.m.

\section{Women's Studies Section}

Program: Saturday, June 27, 9:30-11:00 a.m.

Discussion Group: Saturday, June 27, 11:30

a.m.-12:30 a.m.; Tuesday, June 30, 11:30 a.m. $-12: 30$ p.m.

\title{
ACRL programs in San Francisco
}

\section{This year's conference programs feature teacher education reform, artificial intelligence, and remote access.}

\section{Anthropology and Sociology Section}

"The Future of Social Science Research and Libraries: Toward the Year 2000" (Sunday, June 28, 9:00 a.m. $-12: 30$ p.m.) will be devoted to speculation on the future of social science research and education, and how that future will affect both services and collections in academic and research libraries. Two prominent social scientists-Neil J. Smelser, professor of sociology at the University of California, Berkeley, and James L. Gibbs Jr., professor of anthropology at Stanford-will discuss their views on the social sciences in the year 2000. A panel of librarians (Barton M. Clark, G. Edward Evans, and Mark Sandler) will speculate on how academic libraries might respond to those changes.

ANSS will sponsor a tour of the Robert H. Lowie Museum of Anthropology at the University of California, Berkeley, on Tuesday afternoon, June 30, 1987. For further information see the May issue of "ANSS Currents" or contact Stephen MacLeod,
Main Library, University of California, P.O. Box 19557, Irvine, California 92713.

\section{Art Section}

"Image and Imagination: Adapting New Technologies for Scholarship in the Arts" (Monday, June 29, 9:30 a.m.-12:30 p.m.), cosponsored by the ACRL Audiovisual Committee, will feature speakers David C. Miller on CD-ROM graphic images, Brian O'Connor on computer analysis of images and their structural attributes, and Chingchih Chen on interactive videodisc technology-especially her Project Emperor-I, a videodisc providing access to multimedia information sources for scholarly research in the arts. Two double-sided NTSC CAV videodiscs entitled "The First Emperor of China" will be used to demonstrate the enormous potential of interactive videodisc for fast, random, online access to a large multi-media information bank. 


\section{Asian and African Section}

"Asia and Africa in Undergraduate Library Collections" (Monday, June 29, 9:30 a.m.-12:30 p.m.), cosponsored by the International Relations Round Table and RTSD's Cataloging: Asian and African Materials Committee, will suggest strategies to ensure inclusion of or access to Asian and African materials during a period of expanding interest in international studies among undergraduates. Speakers will include: Evan I. Farber, Earlham College; Corinne Nyquist, SUNY College at New Paltz; Ernest J. Valenzuela, Dept. of History, Diablo Valley College; C.P. Chen, University of California, Berkeley; Barbara J. Henn, Indiana University; Eleanor H. Pinkham, Kalamazoo College.

\section{Audiovisual Committee}

"Libraries, Computers and Audiovisual Resources: Organizational Implications of Integrated Services" (Saturday, June 27, 2:00-4:00 p.m.), cosponsored by the LAMA/LOMS Comparative Library Organization Committee, will discuss the organizational framework for integrated library, computer, and audiovisual services in a university setting, emphasizing the administrative and management aspects. Panelists will be David Barnard, dean for learning resources, University of Wisconsin-Stout; James May, associate vice president for information services, California State University-Chico; and Thomas Michalak, associate director for information services, CarnegieMellon University. The panel will be moderated by Carla Stoffle, associate director, University of Michigan Libraries.

\section{Bibliographic Instruction Section}

"Learning to Teach: Promoting Quality in Bibliographic Instruction" (Sunday, June 28, 2:00-5:30 p.m.) will provide information on continuing education, staff development and training, teaching techniques, and the role of library schools in the training process. Speakers will include Eric Kristensen, associate director of the HarvardDanforth Center for Teaching and Learning, on "The Librarian As Classroom Teacher"; Virginia Tiefel, director of library user education, Ohio State University, on "Planning and Developing a Teaching Effectiveness Program for Librarians"; and Patricia Breivik, director of Auraria Library, Denver, on "Librarians and Academic Program Excellence." The program will also feature the presentation of the Miriam Dudley BI Librarian of the Year Award to Evan Farber, librarian at Earlham College.

The program will be followed by a reception and cash bar from 5:30 to 6:30 p.m. in honor of the section's 10th anniversary. Joining in the festivities will be original Think Tank participants, past leaders in section activities, friends, and supporters. A special anniversary dinner is planned for later in the evening. Details about the dinner may be obtained from Laurie Sabol, Jerome Library, Bowling Green State University, Bowling Green, $\mathrm{OH}$ 43402 , or through the BIS Newsletter.

\section{College Libraries Section}

"Sharing Ideas and Trying a Format" (Saturday, June 27, 9:30 a.m.-12:30 p.m.) will consist of small-group sessions that will examine such issues as situations common to specific types of college libraries, educating faculty, budget planning, networking, standards, and document delivery options. The discussion topics were suggested by CLS National Advisory Council participants and other section members. Action items will go to the CLS Executive Committee for consideration.

CLS is also holding a membership meeting and standards workshop (Sunday, June 28, 9:30 a.m. $-12: 30$ p.m.) which will bring together all the members of the section's chapter-based National Advisory Network. The workshop, presented by Larry Hardesty and Jacqueline Morris, will provide background on the 1986 Standards for College Libraries.

\section{Community and Junior College Libraries Section}

"Megabytes without Megabucks" (Saturday, June 27, 9:00-11:00 a.m.) will explore the use of inexpensive microcomputers for library services. Dan Koenig, dean of learning resources at Piedmont Technical College, will cover automated cir-

\section{ACRL President's Program}

This year's President's Program, “Academic Colleagues in Concert," will be held at the McLaren Center at the University of San Francisco (Monday, June 29, 2:00-5:00 p.m.). Speakers and participants will discuss improving the higher education environment through closer cooperation of librarians, faculty, and administrators. ACRL President Hannelore B. Rader will moderate the program, which includes as speakers: Sheila Kaplan, chancellor of the University of Wisconsin-Parkside, on "The Academic Library's Role in Research"; John Lanning, professor of chemistry at the University of Colorado-Denver, on "The LibraryFaculty Partnership in Curriculum Development"; and Michael Kathman, director of the library/computer center at the College of St. Benedict/St. Johns University, on "The Impact of Technology on Information Handling in Higher Education." Group discussions following the presentations will result in an action agenda for the 1990s.

Maps to the program site will be available at the ACRL desk in San Francisco. 


\section{BETTER \\ COMMUNICATION...}

THE DREAM LIVES ON

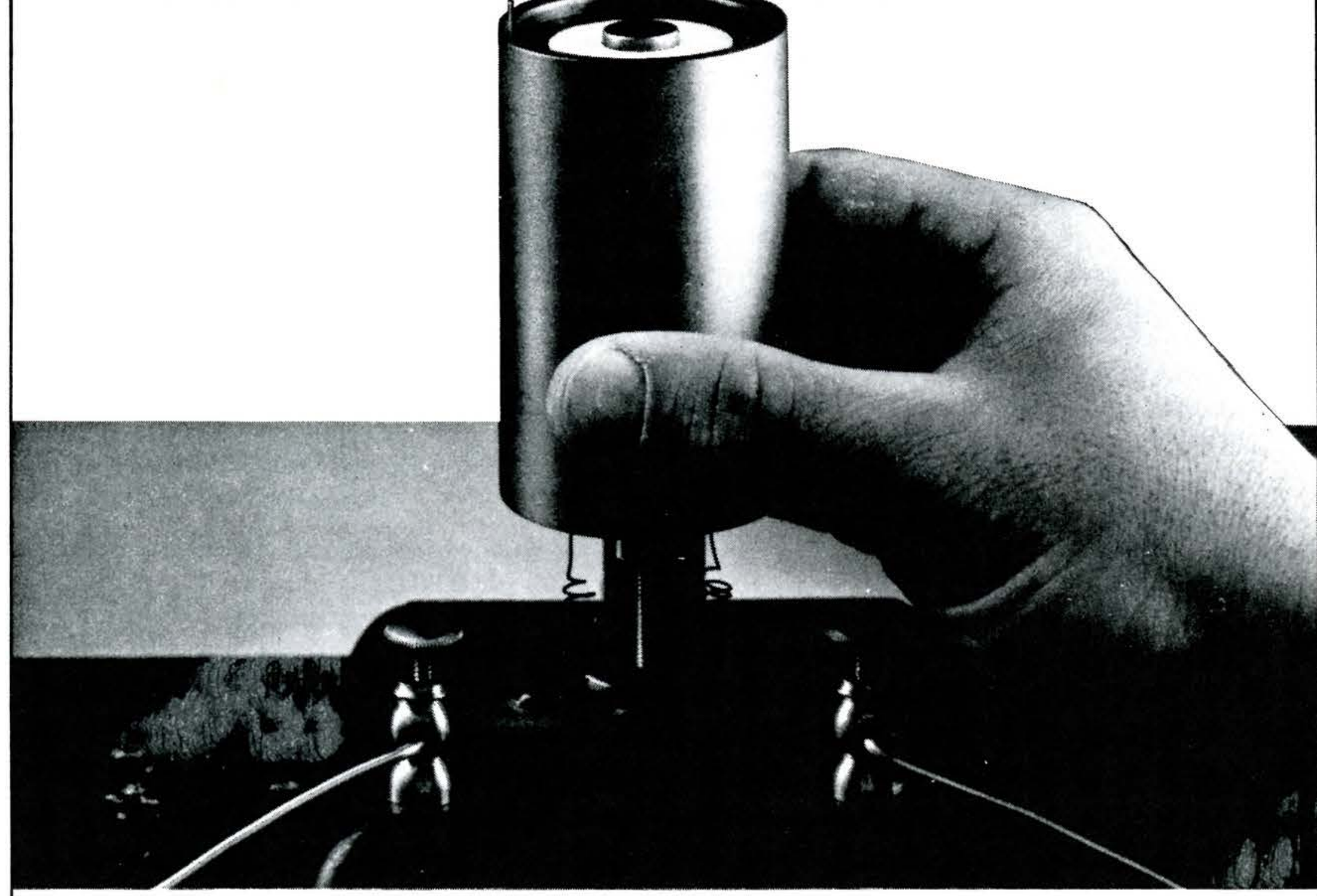

Since that particular day in March, 1876, when Mr. Bell used his new invention to call for his assistant, information management hasn't been the same.

Today's information manager is a communications specialist. And when you provide information on demand, you demand support from people who pursue excellence as avidly as Mr. Bell.

EBSCO, for its part, has explored the application of international telecommunications to the world of serials. And put people with experience at the other end of the line.

For contemporary subscription services that reach the highest levels of accomplishment, communicate with EBSCO.

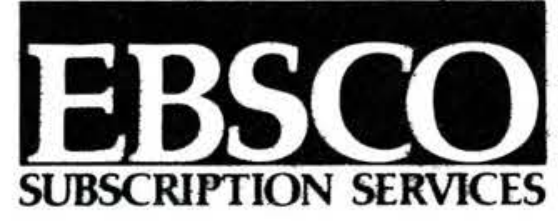


culation, online catalogs, serials control, retrospective conversion, and acquisitions.

The section will also host a dinner in Chinatown (Friday, June 26, 6:30-9:30 p.m.) at Louie's of Grant Avenue, 1014 Grant Ave. Harvey Varnet and Carol Jones will deliver a slide presentation on their library work at Sultan Qaboos University, Oman. Tickets are $\$ 20$, with reservations due by June 14. Send a check or money order payable to Gladys Chaw, 1634 Morago St., San Francisco, CA 94122.

This year's CJCLS tour program, "California Update: Will State Participation Increase Support?" (Monday, June 29, 8:00 a.m.-1:00 p.m.), will be held at Foothill Community College, Los Altos Hills. Speakers will include Lois Marriott, Gregg Atkins, and Tobin Clark. Tickets are $\$ 12$ by advance reservation not later than June 14 . Bus transportation and brunch are included. Send check or money order payable to Mary Dolven, 8 Krohn Lane, Oakland, CA 94611.

\section{Education and Behavioral Sciences Section}

"Teacher Education Reform: A Partnership" (Monday, June 29, 9:30 a.m.-12:30 p.m.), cosponsored by the AASL Supervisors Section, will provide information on teacher education reform, the various approaches under consideration, and the role that academic libraries might play in reshaping teacher education. Speakers include Nel Noddings, School of Education, Stanford University; and Jean Lowrie, School of Library Science, University of Michigan.

\section{Heads of Public/Readers Services Discussion Group}

"Organization of Public Services" (Sunday, June 28, 4:30-5:30 p.m.) will feature Peter D. Haikalis (San Francisco State University) and Claudette S. Hagle (University of Dallas) discussing various organizational structures for public services operations that are currently in place in college and university libraries. Pros and cons of various plans will be highlighted; discussion leaders will come prepared with pointed questions concerning organizational structure.

\section{Law and Political Science Section}

"Public Policy Alternative Sources: Access and Use" (Saturday, June 27, 2:00-4:00 p.m.), cosponsored by the SRRT Alternatives in Print Task Force, will highlight the role of alternate sources of public policy information from advocacy groups and research institutes. Speakers will discuss what libraries can do to identify, acquire, index, cata$\log$, and facilitate access to this kind of grey literature. The panel will consist of Ben Bagdikian, dean of the School of Journalism, University of California, Berkeley; Francis Moore Lappe, Institute for
Food and Development Policy; Marc Levin, associate librarian of the Institute of Governmental Studies, University of California, Berkeley; and Terry Link, reference librarian and journalism bibliographer, Michigan State University Library.

\section{Professional Education Committee}

"Continuing Education and the Adult Learner" (Monday, June 29, 9:30-11:00 a.m.), cosponsored by the ACRL CE Courses Advisory Committee, will focus on the characteristics of adult learners, who bring widely differing preferences, backgrounds and skills into the learning situation and often have immediate needs.

\section{Rare Books and Manuscripts Section}

"The Book Arts in the San Francisco Bay Area" (Sunday, June 28, 2:00-5:30 p.m.), cosponsored by the ACRL Art Section and the English and American Literature Discussion Group, will be an introductory overview, aimed at the non-specialist librarian, of the wide range of book-related activities in the Bay Area. Panelists will include: D. Steven Corey, special collections librarian at the University of San Francisco; Johanna Goldschmid, special collections librarian at San Francisco Public Library; Sandra Kirshenbaum, editor of Fine Print; Jennifer Larson, proprietor of Yerba Buena Books; Barclay Ogden, head of the Conservation Department at the University of California, Berkeley; and Kathy Walkup, director of the Book Arts Program, Mills College.

To complement the plenary sessions at the RBMS Preconference, June 23-26 (described in C $-R L$ News, March 1987, p. 132), the RBMS Continuing Education Committee has planned a variety of seminars intended to encourage discussion by Preconference participants on practical aspects of the program theme, "Special Collections and New Directions in Humanities Research." Sessions scheduled for Tuesday, June 23, 4:00-6:00 p.m., will focus on "Legal, Medical, and Other Specialized Special Collections" and "Strategies for the Online Catalog." Wednesday afternoon seminars will address "Issues in Publishing Literary Manuscripts," "Transfer of Materials from General Stacks to Special Collections," "Retrospective Conversion for Special Collections," “Archives As Special Collections," "Promoting the Use of Special Collections," and "A Forum on the Guidelines: Professional Practices in the Borrowing of Special Collections Materials for Exhibition Purposes." Also scheduled for Wednesday afternoon is a special demonstration of the RLIN/AMC format.

\section{Research Discussion Group}

"Funding and Publishing a Research Project" (Monday, June 29, 9:30 a.m.-12:30 p.m.) will be a follow-up to the Research Clinic held at ALA Annual Conference in June 1986. The program, in a 
combination lecture and discussion format, will aid researchers in the funding and publishing of a research study. Speakers will be Charles Martell, editor of College \& Research Libraries, and Barbara Foster, assistant professor at Hunter College, New York.

\section{Science and Technology Section}

"Artificial Intelligence: Convergence of Mind and Machine?" (Tuesday, June 30, 9:00 a.m. $-12: 30$ p.m.) will feature as speakers George Johnson, journalist and author of Machinery of the Mind; Nils J. Nilson, chairman of the Computer Science Department at Stanford University; and Philip Smith, of the Department of Industrial and System Engineering at Ohio State University, who will discuss applications of AI techniques to searching the environmental chemistry literature.

\section{Slavic and East European Studies Section}

“Acquisition by Exchange: The Administrator's Viewpoint" (Sunday, June 28, 2:00-4:00 p.m.) will explore administrative objections to reliance on acquisition by exchange and refresh administrative memories as to the advantages of acquisition by exchange. Speakers will include Hugh Olmsted, Harvard College; Angelika Powell, University of Virginia; Peter de la Garza, Hispanic Acquisitions Program, Library of Congress; Carl Deal, University of Illinois; and Joe Narker, University of California, Berkeley.

\section{University Libraries Section}

"Remote Access and the New Library User: Are We Ready?" (Sunday, June 28, 9:30-11:00 a.m.) will address the ways automation can be used to access library resources from points outside the library building and how this access may affect future facility planning, staff organization, traditional reference desk assistance, faculty liaison in terms of collection development, and the delivery of such library programs as bibliographic instruction. The scheduled speakers are Joseph Rosenthal, director of libraries, University of California, Berkeley; and Anne Lipow, library education officer, University of California, Berkeley.

\section{Western European Specialists Section}

"New Directions in Old World Research: Western European Studies from Classical Antiquity to the Renaissance-Implications for Libraries" (Monday, June 29, 9:30 a.m.-12:30 p.m.), cosponsored by the ACRL Rare Books and Manuscripts Section and the RASD History Section, will identify trends in the study of Western Europe during its earlier periods and explore their implications for the provision of materials and services in an academic or other research library. Three papers will be presented by teaching faculty members from
Bay Area universities and three academic librarians representing different aspects of library operations will respond. The faculty members will be Thomas N. Habinek, Classics Department, University of California, Berkeley; Mary Wack, English Department, Stanford University; and Sally Scully, History Department, San Francisco State University. Librarians responding will be Chris D. Ferguson, University of California, San Diego; Barbara Halporn, Indiana University; and Kathleen Reed, University of Pennsylvania.

\section{Women's Studies Section}

"Information for, by and about Women of Color in the United States" (Saturday, June 27, 9:30 a.m. $-12: 30$ p.m.), cosponsored by the ALA Committee on the Status of Women in Librarianship, will describe academic reference services to AfroAmerican, Mexican American, Native American, and Asian American women. Speakers will include Lillian Castillo-Speed, Chicano Studies Library, University of California, Berkeley; Edith Fisher, ethnic studies bibliographer, University of California, San Diego; Wei Chi Poon, Asian American Studies Library, University of California, Berkeley; and Binnie Tate Wilkin, School of Library and Information Studies, University of California, Berkeley. The program will be moderated by Jacquelyn Marie, University of Southern California, Santa Cruz.

\section{Letter}

\section{BI for foreign students}

\section{To the Editor:}

I have been a librarian in Kenya for more than 20 years and so have become very interested in teaching library skills to African students. My Ph.D. research at Florida State University's School of Library and Information Studies was in the area of bibliographic instruction in Africa.

The article by Wendy Moorhead at Roosevelt University (C\&RL News, October 1986, pp.585-87) supports the findings of my research: 1) the lecture method is not effective for many Third World students; 2) cooperation, rather than competition, promotes learning; 3) students learn from working in small groups; 4) the librarian should be nearby for consultation; 5) hands-on experience is essential.

Although my research was conducted to determine better BI methods for use here, I believe that the findings above and others in the study are important for BI librarians dealing with international students at American colleges and universities. Dorothy N. Bowen, Library Director, Nairobi Evangelical Graduate School of Theology. 